\title{
Progressive Constitutionalism and Alternative Movements in Law
}

\author{
AMY J. COHEN ${ }^{*} \&$ MiCHAL ALBERSTEIN ${ }^{\dagger}$
}

TABLE OF CONTENTS

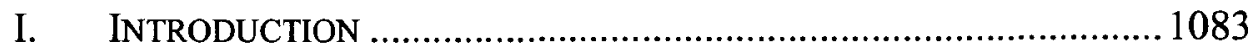

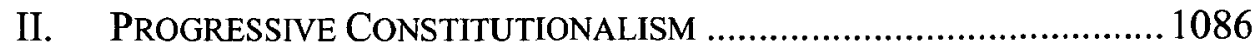

III. A PROGRESSIVE HISTORY OF ADR? ...................................... 1090

IV. THE LAWS OF ALTERNATIVES....................................................... 1097

V. QUESTIONS FOR PROGRESSIVE CONSTITUTIONALISM: POPULAR DEBATES ABOUT HEALTH CARE REFORM ...................................1103

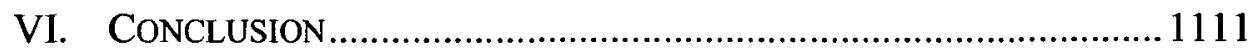

\section{INTRODUCTION}

Theorists of alternative dispute resolution (ADR) will find a prominent strand of U.S. constitutional theory both familiar and new: it theorizes a break from traditional forms of constitutional interpretation and adjudication in the name of democracy, deliberation, empowerment, and the revitalization of politics. Variously called progressive constitutionalism, ${ }^{1}$ popular constitutionalism, ${ }^{2}$ and democratic constitutionalism ${ }^{3}$ (we don't attempt to parse

* Associate Professor of Law, The Ohio State University Moritz College of Law.

† Senior Lecturer, Faculty of Law, Bar Ilan University. The authors would like to thank Ori Aronson, Martha Chamallas, Garry Jenkins, Genevieve Lakier, Carrie MenkelMeadow, Marc Spindelman, Mark Tushnet, Annecoos Wiersema, and Saul Zipkin for comments and helpful conversation, and Sanya Shah and Courter Shimeall for research and bibliographic assistance.

${ }^{1}$ See, e.g., RoBIn West, Progressive Constitutionalism: ReCONSTRUCTING THE FOURTEENTH AMENDMENT 282-85 (1994) [hereinafter WEST, PROGRESSIVE COnstitutionalism]; Marc Spindelman, Toward a Progressive Perspective on Justice Ginsburg's Constitution, 70 OHIO ST. L.J. 1115 (2009); Robin West, Progressive and Conservative Constitutionalism, 88 MiCH. L. REV. 641, 713-17 (1990) [hereinafter West, Progressive and Conservative Constitutionalism]; Robin West, Is Progressive Constitutionalism Possible?, 4 WIDENER L. SYMP. J. 1 (1999).

${ }^{2}$ See, e.g., Larry D. Kramer, THE People Themselves: Popular Constitutionalism and Judicial Review (2004) [hereinafter KRaMer, The PEople THEMSElves]; MARK TUSHNET, TAKING THE CONSTITUTION AWAY FROM tHE COURTS (1999); Larry D. Kramer, Popular Constitutionalism, Circa 2004, 92 CALIF. L. REV. 959 (2004) [hereinafter Kramer, Popular Constitutionalism]; Todd E. Pettys, Popular Constitutionalism and Relaxing the Dead Hand: Can the People be Trusted?, 86 WASH. U. L. REV. 313 (2008).

${ }^{3}$ See, e.g., Robert Post \& Reva Siegel, Roe Rage: Democratic Constitutionalism and Backlash, 42 HARV. C.R.-C.L. L. REV. 373, 374-76 (2007). 
either their complex elements or differences here ${ }^{4}$ ), one common aspiration of this new praxis is to create (or revive) a political-legal discourse that does not depend exclusively on adjudication for authoritative meaning of constitutional text. Proponents of this movement offer both critiques of constitutional adjudication and, to varying degrees, proposals for reform.

In this Article, we consider one significant jurisprudential element of this extrajudicial strand of constitutional theory: its anti-authoritarian impulse. In its most ambitious formulation, extrajudicial constitutionalism strives to return authority to "the people themselves" to deliberate and reach decisions about the legal rules that the Constitution enables and requires. ${ }^{5}$ It emphasizes the role of bottom-up participation in the development of the social order and the potential of dialogue and deliberation in the creation of constitutional norms. As Larry Kramer argues, "[i]t does not assume that authoritative legal interpretation can take place only in courts, but rather supposes that an equally valid process of interpretation can be undertaken in the political branches and by the community at large." ${ }^{6}$ Extrajudicial constitutionalism thus challenges core liberal

${ }^{4}$ For an overview and typology of different forms of extrajudicial constitutionalism, see David E. Pozen, Judicial Elections as Popular Constitutionalism, 110 COLUM. L. REv. 2047, 2053-64 (2010).

${ }^{5}$ In this Article, we focus on this more directly populist impulse within extrajudicial constitutionalism. We should note, however, that several contributions to the field place greater emphasis on the role of legislators and the executive branch in constitutional interpretation. On legislative constitutionalism, see, for example, WeST, ProgressIVE CONSTITUTIONALISM, supra note 1 , at 285-89 (proposing to "reorient[] progressive constitutional discourse toward legislative rather than adjudicative action, and toward a congressional rather than a judicial audience"); Neal Kumar Katyal, Legislative Constitutional Interpretation, 50 DUKE L.J. 1335, 1338 (2001) ("I shall argue that Congress, not the Court, is often best situated to make the judgments necessary to create a Constitution of relevance to Americans today."); Robin West, The Missing Jurisprudence of the Legislated Constitution, in THE CONSTITUTION IN 2020, at 79 (Jack M. Balkin \& Reva B. Siegel eds., 2009) [hereinafter West, Missing Jurisprudence]. See also MARK TUSHNET, WEAK COURTs, Strong Rights: Judicial Review and Social Welfare Rights IN COMPARATIVE CONSTITUTIONAL LAW, at ix (2008) (proposing a model of "weak-form judicial review" where "courts assess legislation against constitutional norms, but do not have the final word on whether statutes comply with those norms"); Jeremy Waldron, The Core of the Case Against Judicial Review, 115 YALE L.J. 1346 (2006) (arguing against judicial review of legislation). On executive constitutionalism, see, for example, Jedediah Purdy, Presidential Popular Constitutionalism, 77 FordHAM L. REV. 1837 (2009); Keith E. Whittington, Presidential Challenges to Judicial Supremacy and the Politics of Constitutional Meaning, 33 POLITY 365 (2001). For an overview of departmentalism (or the idea that each branch of government has independent interpretative authority to assess the constitutionality of government action), see Larry Alexander \& Lawrence B. Solum, Popular? Constitutionalism?, 118 HARV. L. REV. 1594, 1609-15 (2005) (reviewing KRAMER, THE PEOPLE THEMSELVES, supra note 2).

${ }^{6}$ Larry D. Kramer, "The Interest of the Man": James Madison, Popular Constitutionalism, and the Theory of Deliberative Democracy, 41 VAL. U. L. REV. 697, 700 (2006); see also TUSHNET, supra note 2, at 182 ("Populist constitutional law ... treats 
assumptions about how sovereign law is produced as an instrument for governance and social change. In some variations, it calls for the public to "participate in shaping constitutional law more directly" and recognizes ordinary individuals as valid interpreters of legal text (empowered to act through the representative/electoral process as well as through direct action and social movement activism). ${ }^{8}$ As Mathew Adler suggests, some strands of extrajudicial constitutionalism appear to propose, quite radically, to make ordinary citizens coequal with judges and other officials in their capacity to recognize and validate socio-legal practices and understandings as constitutional law. ${ }^{9}$

We compare extrajudicial constitutionalism's challenge to a similar, if more prosaic and less controversial, anti-authoritarian movement in law-namely, mediation and its practice of lawmaking by private individuals that has evolved as part of the U.S. ADR movement. ${ }^{10}$ As a jurisprudential ideal, mediation authorizes ordinary people to decide their own destinies and create the legal rules that will govern their disputes and collective decisions. ${ }^{11}$ We thus use this Article as an opportunity to consider what, if anything, movements like extrajudicial constitutionalism and extrajudicial dispute resolution hold in common and what the differences between them suggest for the possibilities and limitations of this new constitutional praxis to generate progressive social change.

To that end, we offer in Part II a brief sketch of what theorists have in mind when they use the term progressive constitutionalism-the topic of our Symposium. We do not attempt to describe this complex literature in any

constitutional law not as something in the hands of lawyers and judges but in the hands of the people themselves." ); Mark Tushnet, Popular Constitutionalism as Political Law, 81 CHI.-KENT L. REV. 991, 999 (2006) ("What is distinctive about popular constitutionalism is that the courts have no normative priority in the conversation.").

${ }^{7}$ TUSHNET, supra note 2 , at 194.

${ }^{8}$ See, e.g., id. at 181 ("[T] he Constitution belongs to us collectively, as we act together in political dialogue with each other-whether we act in the streets, in the voting booths, or in legislatures as representatives of others.").

${ }^{9}$ Matthew D. Adler, Popular Constitutionalism and the Rule of Recognition: Whose Practices Ground U.S. Law?, 100 Nw. U. L. REV. 719, 721-23 (2006).

${ }^{10}$ ADR today stands for a range of diverse practices and forms including not only negotiation and mediation, but also more authoritative forms of dispute resolution such as professional arbitration. We use the term here, however, to signify a widespread trend in dispute resolution that, as Michael Palmer and Simon Roberts argue, represents a "general move from 'vertical' to 'horizontal' modes of decision-making; . . exemplifies the changing ways in which governmental power may be exerted; and ... reflects disenchantment with entrenched forms of professional domination." MichaEL PALMER \& SIMON ROBERTS, DiSPUTE PROCESSES: ADR AND THE PRIMARY FORMS OF DECISION MAKING 45 (2005).

${ }^{11}$ For an early formulation of this ideal, see Lon L. Fuller, Mediation-Its Forms and Functions, 44 S. CAL. L. REV. 305, 339 (1971) (arguing that mediation "seems to resist [the] tendency to subsume every kind of ordering under the rubric of 'power' or 'authority'"). 
comprehensive way. Instead, we focus on some of its normative antiauthoritarian aspirations. In Part III, we sketch an anti-authoritarian and progressive account of mediation, tracing its roots to neighborhood and community justice programs in the 1970s and 1980s - an account that has largely fallen away from ADR's institutional memory as mediation is now more commonly considered a tool of privatization, cost savings, court management, and other settlement ideologies. In Part IV, we suggest that as taught and theorized today, mediation is best understood neither as a tool of progressive social change nor of neoliberal governance, but rather as a reconstructive jurisprudential ideal organized around five recurring themes that we refer to as the "laws of alternatives." In Part V, we apply these "laws" or principles to consider an example of extrajudicial constitutionalism in action. We conclude by arguing that these five themes offer insight into, first, how bottom-up democratic impulses in law are transformed into institutionalized, practical, depoliticized projects and, second, the possibilities and tradeoffs of pursuing progressive constitutionalism through similar means.

\section{Progressive CONSTITUTIONALISM}

Because our Symposium was devoted to progressive constitutionalism, we take our definitional cue from its organizer, Marc Spindelman. Spindelman uses the term to capture an aspirational convergence between left progressive politics, on the one hand, and popular constitutional engagement, on the other. He writes:

[T] he version [of progressive constitutionalism] I have in mind ... maintains that progressive politics - and the freedoms towards which they aim-would stand a better chance of success than they presently do if the Supreme Court were to stand back and give the political processes their head. As the Court pulled back, political deliberations would need to become more thoroughly informed than they currently are by an active sense of constitutional fidelity, duty, and purpose. ...12

This argument-that political processes will advance progressive goals better than the Supreme Court-rests on the optimistic assertion that participation and deliberation are a better means than adjudication to achieve social freedoms and rights. Spindelman continues:

Needless to say, this view of progressive constitutionalism takes a critical position on the role of courts in our constitutional system, which puts it in some tension with liberal orthodoxy. Liberal convention teaches that courts are needed to protect us, especially our individual and equality rights.... [P]rogressive constitutionalism notices that judicial superintendence of our

${ }^{12}$ Spindelman, supra note 1 , at 1115-16. 
Constitution, including our individual and equality rights, has a distinctly double-edged quality to it. Even where it has helped secure freedom, it has regularly, if not always, done so by creating potential impediments to further social progress and reform. ${ }^{13}$

Spindelman thus couples his affirmation of political processes with a critique of liberal legalism that points to the "double-edged quality" of court decisions. By trying to impose order from above, court decisions produce opposition, even alienation, from below. "Hence," he offers "progressive constitutionalism's bid":

What if politics were not diminished in these ways? ... What if the Court's role in our system were downsized to give politics, and the possibilities of progressive reform, a fighting chance? ${ }^{14}$

In these quotations, Spindelman positions courts as causal actors that constrict and constrain American political energy. Supreme Court victories, he reasons, quell an "active sense" of popular engagement and civic duty. As such, scaling back the power and reach of the Court could accordingly "vitally engage[] [politics], once again."15

In proposing to decenter the role of courts in constitutional interpretation, Spindelman invokes Robin West's description of progressive constitutionalism, which likewise includes a cutting critique of adjudication. "Adjudicative law," West argued over two decades ago, "is persistently authoritarian: demonstration of the 'truth' of legal propositions ... relentlessly requires shows of positive authority." 16 Even more, "adjudication is profoundly elitist, hierarchic, and nonparticipatory. It is itself a form of domination that creates experiences of subordination." 17 For West, then, progressivism is in part an institutional value. To take it seriously, progressives should approach constitutional interpretation with active, skeptical questions about the limitations of adjudication and a countervailing commitment to participatory democratic reform (for her, particularly in the legislative arena). ${ }^{18}$ Moreover, like Spindelman, she links the work of changing institutional structures to the work of changing the legal consciousness of extrajudicial actors: "We need to break the jurisprudential

${ }^{13} \mathrm{Id}$. at 1116 .

14 Id. at 1117 .

${ }^{15}$ Id. at $1117 \mathrm{n} .11$ (citing James B. Thayer, The Origin and Scope of the American Doctrine of Constitutional Law, 7 HARV. L. REV. 129, 155-56 (1893)).

${ }^{16}$ West, Progressive and Conservative Constitutionalism, supra note 1, at 714.

${ }^{17}$ Id. at 715 .

${ }^{18}$ To that end, many of West's prescriptions involve revitalizing the role of legislatures in constitutional interpretation. See, e.g., West, Missing Jurisprudence, supra note 5. 
habits of mind," she argues, "that put, not just the Constitution, but our political morality ... and our understanding of legalism itself in the hands of judges."19

These visions of progressive constitutionalism also overlap with a recent spate of challenges to judicial supremacy. ${ }^{20}$ For example, in his work on popular constitutionalism, Larry Kramer theorizes how judicial supremacy constrains popular mobilization. "[W]hether we actively oppose a decision or course of decisions," he explains, "will depend on whether we think the decision or course of decisions is legitimate. But judgments about legitimacy turn not only on whether we agree or disagree with the Court's results, but also on whether we feel entitled to disagree and, more important still, to act on our disagreement."21 Thus Kramer reasons that under conditions of judicial supremacy, citizens come to believe "that, whatever they may think about the Justices' constitutional rulings, it is not their place to gainsay the Court."22 By contrast, popular constitutionalism describes a state of affairs in which subjects feel empowered to disagree with judicial pronouncements and to organize their own strategies for action. Kramer, in fact, is relentlessly committed to a view of the world in which ordinary people have the capacity, attitude, and will to engage in acts of constitutional interpretation and reform.

Finally, Robert Post and Reva Siegel's work on democratic constitutionalism similarly proposes to analyze extrajudicial practices of constitutional interpretation with a special focus on social movements. ${ }^{23}$ Although unlike Kramer, Post and Siegel endorse courts as potential enablers of negotiated interaction among lay and judicial actors, they nonetheless share some of Kramer's overarching normative sensibilities. ${ }^{24}$ They worry, for instance, that "acculturated deference to judicial authority may sap the nation of the sense of entitlement, responsibility, and urgent normative engagement that

${ }^{19}$ Robin West, Unenumerated Duties, 9 U. PA. J. ConsT. L. 221, 259-60 (2006); see also Marc Spindelman, House Rule XII: Congress and the Constitution, 72 OHIO ST. L.J. $1317(2011)$.

${ }^{20}$ For a detailed summary of these challenges, see Ori Aronson, Inferiorizing Judicial Review: Popular Constitutionalism in Trial Courts, 43 U. MiCH. J.L. REFORM 971, 974-82 (2010). For a critique of these challenges, see Erwin Chemerinsky, In Defense of Judicial Review: The Perils of Popular Constitutionalism, 2004 U. ILL. L. REV. 673.

${ }^{21}$ KRAMER, THE PEOPLe THEMSELVES, supra note 2, at 231.

${ }^{22} \mathrm{Id}$. at 233 . He argues further: "It is not too much to say that [judicial supremacy] has fundamentally altered the meaning of republican citizenship by, as a conceptual matter, taking ordinary people out of the process of shaping constitutional law." Id.

${ }^{23}$ See, e.g., Post \& Siegel, supra note 3, at 379-87.

${ }^{24}$ See id. at 379 (" $[\mathrm{D}]$ emocratic constitutionalism does not seek to take the Constitution away from courts.... [But] [u]nlike a juricentric focus on courts, democratic constitutionalism appreciates the essential role that public engagement plays in guiding and legitimating the institutions and practices of judicial review... [, and it] observes that adjudication is embedded in a constitutional order that regularly invites exchange between officials and citizens over questions of constitutional meaning."). 
is necessary for the exercise of constitutional self-governance." 25 All these authors thus theorize how hierarchical adjudicatory institutions shape the self and social understandings of the governed. And all accordingly aim to preserve spaces for nonjudicial constitutional interpretation and active self-governance as its own anti-authoritarian end. To this aspiration, progressive constitutionalism adds the idea that scaling back judicial supremacy can revitalize left politics and policy ambitions - or at least, in Spindelman's words, give left politics "a fighting chance."26

This structuralist critique of the twin ills of judicial authority and extrajudicial passivity should sound familiar to theorists of ADR, and especially of mediation. Mediation calls for a turn away from institutionalized interpretations of law by formal decision makers in favor of engaging people themselves in law-like deliberations albeit on a very different scale: mediation is concerned with how lay actors participate in arranging their own private, everyday legal relations without the direct coercion of adjudicative law, and it does not generally engage with questions of constitutional interpretation and large-scale social ordering. For this reason, analysts could surely emphasize the distinctions, not the similarities, between constitutional law and the private law of mediation. Indeed, for Kramer, it is precisely the claim that constitutional law is more fundamental, political, and constitutive of national identity than "ordinary law" that makes it the proper subject of popular control. ${ }^{27}$ But regardless of whether one agrees with this distinction, ${ }^{28}$ socio-legal scholars have argued for decades that ordinary people's understandings of legality (constitutional or otherwise) are shaped in significant ways not through moments of intense political and social mobilization but rather through mundane, though highly influential, everyday encounters with law in localized venues and forums. ${ }^{29}$ Thus to the extent progressive constitutionalists aim to

${ }^{25}$ Robert Post \& Reva Siegel, Popular Constitutionalism, Departmentalism, and Judicial Supremacy, 92 CALIF. L. REv. 1027, 1037 (2004).

26 Spindelman, supra note 1 , at 1117.

${ }^{27}$ For Kramer, constitutional or "fundamental law" is enacted by the people to regulate government and is therefore the proper subject of "direct supervision and correction by the superior authority of 'the people." KRAMER, THE PEOPLE THEMSELVES, supra note 2, at 2930. By contrast, "ordinary law" is made by government to regulate the people and is thus the proper subject of authoritative government interpretation typically through litigation and judicial settlement. Id. at 155 .

${ }^{28}$ Richard Ross, for example, questions its explanatory power in the pre-revolutionary context (from which Kramer derives it) where "the overlap of state and society was so profound." Richard J. Ross, Pre-Revolutionary Popular Constitutionalism and Larry Kramer's The People Themselves, 81 CHI.-KENT L. REV. 905, 906 (2006). Even those who find Kramer's distinction a useful analytic tool suggest it is invariably fuzzy. See, e.g., Tushnet, supra note 6, at 997 ("[W]e are not going to be able to make strong claims about the inherent structure of constitutional law as political [i.e., popular] law ....").

${ }^{29}$ See generally Patricia EWICK \& SUSAN S. Silbey, THe COMMON PLACE OF LAW: STORIES FROM EVERYDAY LIFE (1998). 
catalyze lay participation in legal/constitutional interpretation, they might want to know what has happened within the field of ADR.

\section{A PROGRESSIVE HISTORY OF ADR?}

ADR and its core discipline of mediation do not feature in the literature on progressive constitutionalism. And likely for good reason: why would a leftliberal legal movement with aspirations for revitalizing progressive politics want to claim ADR among its allies? We would be hard-pressed to argue that U.S. ADR has itself been responsible for advancing any sort of egalitarian redistribution of resources, systemic race or gender equality, or other kinds of left social change. To the contrary, it has been the sustained object of a doubleedged critique: that it erodes progressive state-enforced rights ${ }^{30}$ and simultaneously expands the coercive power of the state into previously less accessible social spaces. ${ }^{31}$ Although we do not analyze these complex claims here, we certainly agree with critics that U.S. ADR has been shaped by the same individuated neoliberal policies that have informed our courts and legislatures in recent decades. ${ }^{32}$ Today, however, as we witness a proliferation of legal

${ }^{30}$ See, e.g., Laura Nader, From Legal Process to Mind Processing, 30 FAM. \& CONCILIATION CTS. REV. 468, 468, 472 (1992) (describing ADR as an intentional "effort to quell the rights movements (civil rights, women's rights, consumer rights, environmental rights)"); see also JEROLD S. AUERBACH, JUSTICE WITHOUT LAw? 128 (1983) ("Nothing, it seemed, propelled enthusiasm for alternative dispute settlement like a few legal victories that unsettled an equilibrium of privilege."); CHRISTINE B. HARRINGTON, SHADOW JUSTICE: THE IDEOLOGY AND INSTITUTIONALIZATION OF ALTERNATIVES TO COURT 96-99 (1985) (characterizing the application of mediation to consumer, family, and minor criminal disputes as "a response to rights movements"); Sally Engle Merry, Disputing Without Culture, 100 HARV. L. REv. 2057, 2072 (1987) (reviewing STEPHEN B. GOLDBERG ET AL., DISPUTE RESOLUTION (1985)) (proposing that ADR proponents "may be responding to the presence of new users in the courts" bringing "claims about domestic violence, neighborhood harassment, sexual harassment on the job, discrimination, faulty goods, shoddy medical service, and deteriorated rental housing").

${ }^{31}$ See, e.g., HARRINGTON, supra note 30 , at 130 (arguing that mediation "expands the state's role in identifying and channeling order maintenance problems"); RICHARD HofrichteR, NeIGHBorhoOd Justice IN CAPITAlist Society: THE EXPANSION OF THE INFORMAL STATE, at $\mathrm{xxx}$ (1987) (arguing that informal dispute resolution "penetrates community social life and potentially contains political and social disorder in a manner determined by but disguised within its form as an apparatus of the state"); Richard L. Abel, Introduction to 1 THE POLITICS OF INFORMAL JUSTICE: THE AMERICAN EXPERIENCE 1, 6 (Richard L. Abel ed., 1982) (arguing that informal dispute resolution enables the state to expand "its control so as to manage capital accumulation and defuse the resistance this engenders").

${ }^{32}$ See generally Amy J. Cohen, Dispute Systems Design, Neoliberalism, and the Problem of Scale, 14 HARV. NEGOT. L. REV. 51 (2009) [hereinafter Cohen, Dispute Systems Design]; Amy J. Cohen, Revisiting Against Settlement: Some Reflections on Dispute Resolution and Public Values, 78 FORDHAM L. REV. 1143 (2009). 
reform projects that, like progressive constitutionalism, call for renewed commitments to participatory democracy and popular mobilization, we think it is useful to recall that once-influential strands of $A D R$ were in fact organized around a similar set of ambitions.

Modern ADR was born in the late 1970s and early 1980s, at roughly the same moment that Kramer claims that an acceptance of judicial supremacy became commonplace. ${ }^{33} \mathrm{Kramer}$ characterizes this period as a highwater mark for liberal faith in the progressive power of courts and as a time when many liberal legal elites came to share anti-democratic attitudes with their conservative counterparts about the institutions empowered to interpret law. 34 One suggestive way, then, to understand ADR's emergence during this period is as a reaction to this anti-democratic sentiment from above. Although there are more cynical and elite-driven explanations for ADR's rapid ascension in U.S. law, ${ }^{35}$ certainly at least part of the impetus behind the movement was democratic - it reflected a desire among a group of idealistic practitioners and scholars to transform ordinary people from passive subjects into empowered ones by encouraging them to "discover that they need not be wholly dependent on outside institutions, legal or otherwise, to solve their problems." 36

${ }^{33}$ Kramer, Popular Constitutionalism, supra note 2, at 963-64 (“[B]y the 1980s, most protests that touched on constitutional matters were being directed at rather than against the Court and acceptance of judicial supremacy seemed to become the norm.").

${ }^{34}$ Id. at 964-66. Kramer traces how "as Warren Court activism crested in the mid1960 s, a new generation of liberal scholars discarded opposition to courts and turned the liberal tradition on its head by embracing a philosophy of broad judicial authority." Id. at 965-66.

${ }^{35}$ Legal elites explicitly promoted ADR to rationalize court systems, which they worried were overburdened by congestion and delay. See, e.g., Warren E. Burger, Agenda for 2000 A.D. - A Need for Systematic Anticipation, in THE POUND CONFERENCE: PERSPECTIVES ON JUSTICE IN THE FUTURE 23, 31-34 (1979) (complaining of poorly managed courts, increasing workloads, delays and high costs; "it is no longer economically feasible to employ lawyers and conventional litigation processes for many 'minor' or small claims"). But given, as Marc Galanter has shown, that the "litigation explosion" was more rhetorical than real, left critics suspected that the legal establishment's support for ADR in fact reflected conservative backlash against progressive victories won in courts. See, e.g., AUERBACH, supra note 30, at 120-32. See generally sources cited supra note 30. On his challenge to the litigation explosion, see Marc Galanter, The Day After the Litigation Explosion, 46 MD. L. REV. 3 (1986); Marc Galanter, Reading the Landscape of Disputes: What We Know and Don't Know (and Think We Know) About Our Allegedly Contentious and Litigious Society, 31 UCLA L. REV. 4, 10-11, 36-69 (1983).

${ }^{36}$ Robert A. Baruch Bush, Efficiency and Protection, or Empowerment and Recognition? The Mediator's Role and Ethical Standards in Mediation, 41 FLA. L. REV. 253, 267-68 (1989); see also Robert A. BARUCH BUSH \& JOSEPH P. FOLgER, THE PROMISE OF MEDIATION: RESPONDING TO CONFLICT THROUGH EMPOWERMENT AND RECOGNITION, at $\mathrm{xv}$ (1994) ("[M]ediation's greatest value lies in its potential... to change people themselves ...."). 
As an intellectual, and not simply institutional, project, early ADR aspired to answer two sets of criticisms of adjudication. The first set comprised largely left, communitarian, and distinctively feminist critiques of legal rights and legal institutions as hierarchical, abstract, individuated, and hence nontransformative. For example, Carrie Menkel-Meadow, a founding proponent of ADR, reflects that she "had come to see [mediation] as a necessary corrective to the pain and draconian results of courts, with the promise of processes we could see as enriching, empowering, and dare I say, humanely transformative."37 Janet Rifkin similarly characterized mediation as a challenge to "the patriarchal paradigm of law as hierarchy, combat, and adversarialness." 38 Richard Danzig proposed to develop localized dispute resolution forums that would provide "a therapeutic process aimed at conciliation of disputants." 39 Other proponents of informal dispute resolution emphasized its political, rather than merely therapeutic, value as means of progressive reform that could provide alternatives to rights-based litigation, which they often viewed with growing disenchantment. ${ }^{40}$

The second set of criticisms of adjudication (equally as Hayekian in its distrust of centralized authority as left or feminist) emphasized the

${ }^{37}$ Carrie Menkel-Meadow, What Trina Taught Me: Reflections on Mediation, Inequality, Teaching and Life, 81 MINN. L. REV. 1413, 1422 (1997); see also Carrie MenkelMeadow, Portia in a Different Voice: Speculations on a Women's Lawyering Process, 1 BERKELEY WOMEN'S L.J. 39, 54-55 (1985) (suggesting that mediation embodies feminist perspectives that value cooperation over adversarialism).

38 Janet Rifkin, Mediation from a Feminist Perspective: Promise and Problems, 2 LAW \& INEQ. 21, 22 (1984); see also Leonard L. Riskin, Toward New Standards for the Neutral Lawyer in Mediation, 26 ARIZ. L. REV. 329, 332 (1984) (arguing that mediation creates space for caring and interconnectedness, not simply the value of individual autonomy that predominates in adjudication).

${ }^{39}$ Richard Danzig, Toward the Creation of a Complementary, Decentralized System of Criminal Justice, 26 Stan. L. REv. 1, 42-43 (1973); see also Nils Christie, Conflict as Property, 17 BRIT. J. CRIMINOLOGY 1, 3-4 (1977) (arguing that courts and lawyers quite literally expropriate social conflicts from their proper localized relational domain; in his words: "[c]onflicts become the property of lawyers").

${ }^{40}$ See, e.g., Andrew W. McThenia \& Thomas L. Shaffer, For Reconciliation, 94 YALE L.J. $1660,1660,1665$ (1985) (rejecting the view that courts are "the principal source of justice in fragmented modern American society" in favor of a view that people, as part of embedded communities, ask and give justice "to one another"); Carrie Menkel-Meadow, The Many Ways of Mediation: The Transformation of Traditions, Ideologies, Paradigms, and Practices, 11 NEGOT. J. 217, 220 (1995) (articulating "a commitment to mediation as a progressive means for socially transformative ends"); Sally Engle Merry, Albie M. Davis: Community Mediation as Community Organizing, in WhEN TALK WORKS: ProfiLes OF MEDiators 245, 261 (Deborah M. Kolb ed., 1994) (describing Albie Davis's practice of mediation as informed by ideals of social justice and community organizing); William $\mathrm{H}$. Simon, Legal Informality and Redistributive Politics, 19 CLEARINGHOUSE REV. 384 (1985) (interrogating the assumption that procedural formality is more likely than procedural informality to serve redistributive interests or benefit the disadvantaged). 
inefficiencies and paternalism of legal-bureaucratic institutions and the limited capacity of central decision makers to resolve highly contextualized problems under conditions of uncertainty and imperfect knowledge. In law review articles and conferences, early ADR theorists discussed how judges often failed to make reliable predictions about human desires and behavior and to understand the "real" interests of individuals and groups. ${ }^{41}$ In response to both these sets of criticisms, institutions like mediation and neighborhood justice centers strove to be not only expedient and cost-effective, but also contextual, responsive, and transformative. Similarly, these institutions strove to promote not only individual autonomy, bottom-up participation, and self-determination, but also interpersonal connection and social collaboration. By repositioning legal conflict within social and relational contexts, ADR proponents aimed to transcend the limitations of formal law while simultaneously promoting alternative visions of legality.

Perhaps the best institutional example of this capacious vision of dispute processing reform was the community or neighborhood mediation movement that took hold in the United States in the 1970s and early 1980s. Although it would be quickly eclipsed by court-annexed mediation, in its early years, community mediation captured a good deal of foundation and government funding as well as prominent scholarly attention. ${ }^{42}$ Consider, as one famous example, the San Francisco Community Boards (SFCB), which was memorialized in Sally Engle Merry and Neal Milner's 1995 edited volume, The Possibility of Popular Justice: A Case Study of Community Mediation in the

${ }^{41}$ Meyer Elkin, Divorce Mediation: An Alternative Process for Helping Families to Close the Book Gently, CONCILIATION CTS. REV., June 1982, at iii, v ("[]]udges and attorneys ... are set up by society as 'experts' but in reality know very little about the [disputing] family involved and what is best for it."); Robert H. Mnookin, Child-Custody Adjudication: Judicial Functions in the Face of Indeterminacy, 39 LAW \& CONTEMP. PROBS. 226 (1975) (describing the indeterminacy of the best interest standard and the impossibility of predicting the effects of various custody regimes); Leah K. Patton, Settling Environmental Disputes: The Experience with and Future of Environmental Mediation, 14 ENVTL. L. 547, 550 (1984) (suggesting that courts "are not reaching the real issues" in environmental disputes); Barbara Ashley Phillips \& Anthony C. Piazza, The Role of Mediation in Public Interest Disputes, 34 HASTINGS L.J. 1231, 1238 (1983) (suggesting that litigation "may never address many of the real interests involved in the dispute").

${ }^{42}$ For historical and analytical perspectives on the community/neighborhood mediation movement, see generally JENNIFER E. BEER, PEACEMAKING IN YOUR NEIGHBORHOOD: REFLECTIONS ON AN EXPERIMENT IN COMMUNITY MEDIATION 145-73 (1986); DANIEL MCGILLIS \& JOAN MULLEN, NEIGHBORHOOD JUSTICE CENTERS: AN ANALYSIS OF POTENTIAL MODElS (1977); NEIGHBORHOOD JUSTICE: ASSESSMENT OF AN EMERGING IDEA (Roman Tomasic \& Malcolm M. Feeley eds., 1982); Christine B. Harrington \& Sally Engle Merry, Ideological Production: The Making of Community Mediation, 22 LAW \& SOC'Y REV. 709 (1988); Paul Wahrhaftig, An Overview of Community-Oriented Citizen Dispute Resolution Programs in the United States, in 1 THE POLITICS OF INFORMAL Justice: THE AMERICAN EXPERIENCE 75 (Richard L. Abel ed., 1982). 
United States. ${ }^{43}$ Spearheaded by Raymond Shonholtz, a lawyer and law teacher, ${ }^{44}$ the SFCB was launched in 1976 and persists to this day ${ }^{45}$ It was designed, in Shonholtz's words, as a counterpoint to a legal system that "makes adults dependent upon processes that often strip them of their șense of responsibility and integrity" 46 and as a means of "reawaken[ing] citizens to their power as disputants and dispute resolvers." 47

At its inception, the SFCB proposed to develop mediation not simply as a tool to resolve individual disputes, but rather as an institution that could revitalize neighborhoods and empower residents to self-manage their own affairs without relying on the formal legal system..$^{48}$ Mediators were volunteers who called themselves, like disputants, community members. ${ }^{49}$ And as community members, their training was designed explicitly as practice in democratic citizenship. As Shonholtz put it, "[b]y learning how to handle neighborhood disputes, individuals develop the skills and confidence necessary to make politics less alien and more controllable. Politics is transformed ... to the grass roots, where democracy has the best chance of flourishing." 50 Moreover, to build this sense of grassroots politics, the SFCB, unlike many community mediation programs, aimed to operate independently from court, prosecutor, or police referrals. ${ }^{51}$

Despite these aspirations, however, the SFCB did not become a tool of social activism or political transformation. Authors who researched its actual practice note how, over time, rather than promoting bottom-up collective action or structural change, the SFCB adopted a managerial and depoliticized discourse oriented around training, service delivery, civic work, and the communication of emotion.52 Unlike Saul Alinsky-style organizing (also

43 The Possibility of Popular Justice: A CASE Study of Community MEdiation IN THE UNTED STATES (Sally Engle Merry \& Neal Milner eds., 1995).

${ }^{44}$ Raymond Shonholtz, Justice from Another Perspective: The Ideology and Developmental History of the Community Boards Program, in THE POSSIBILITY OF POPULAR JUSTICE, supra note 43, at 201, 209.

45 See COMMUNITY BOARDS, http://communityboards.org/ (last visited Aug. 20, 2011).

46 Shonholtz, supra note 44, at 203.

${ }^{47} \mathrm{Id}$. at 205 .

48 See, e.g., Frederic L. DuBow \& Craig McEwen, Community Boards: An Analytic Profile, in THE PossiBILITY OF POPULAR JUSTICE, supra note 43, at 125, 133.

${ }^{49}$ Barbara Yngvesson, Local People, Local Problems, and Neighborhood Justice: The Discourse of "Community" in San Francisco Community Boards, in THE POSSIBILITY OF POPULAR JUSTICE, supra note 43 , at 379, 380, 396.

50 Shonholtz, supra note 44 , at 242.

${ }^{51}$ DuBow \& McEwen, supra note 48, at 134; cf. AUERBACH, supra note 30, at 131-36 (describing early neighborhood mediation programs that were "sponsored by the Department of Justice and securely located within the judicial system").

52 See generally Laura Nader, When Is Popular Justice Popular?, in THE PossiBILITY OF POPULAR JUSTICE, supra note 43, at 435; Judy H. Rothschild, Dispute Transformation, the Influence of a Communication Paradigm of Disputing, and the San Francisco Community 
popular among left activists at the time), which sought to build community through political strategies of direct action, ${ }^{53}$ the SFCB adopted an ideology of neutrality and, accordingly, declined to promote group interests. ${ }^{54}$ As a result, the SFCB did not, as sympathetic critics wistfully note, "align itself actively with new populist organizations such as Citizen Action and ACORN." 55 Nor did it become a source of locally owned transformation led by people whose newly internalized skills in conflict resolution could help them advance their political aims. Rather, the SFCB attempted to build community through providing dispute resolution services. As a result, disputants were united only by their choice to mediate specific conflicts and by their training in the program-not by structural commonalities such as working class backgrounds or common experiences of subordination. ${ }^{56}$ Barbara Yngvesson, leveling this critique, thus concludes that the SFCB empowered "mediators at the expense of the parties to conflict" by producing relations of management and control rather than conditions for collective action. ${ }^{57}$

Merry and Milner's volume thus suggests that mediation rather quickly and easily became a technique of neutral governance and expertise. Although this was manifestly the case with court-annexed mediation, 58 several researchers documented how it was also-and more surprisingly - an accurate description of a model of community mediation that was explicitly fueled by aspirations for bottom-up empowerment and locally owned activism rather than court rationalization or efficiency maximization. More broadly, critical analysts of mediation observed how ADR's anti-authoritarian drive in fact repressed individuals and collectives-either by the allure of para-professionalism and service provision in the case of community mediation, or through the language

Boards Program, in THE PossibILITY of POPULAR JustiCE, supra note 43, at 265; Douglas R. Thomson \& Frederic L. DuBow, Organizing for Community Mediation: The Legacy of Community Boards of San Francisco as a Social Movement Organization, in THE PossibILITY OF POPULAR JUSTICE, supra note 43, at 169; Yngvesson, supra note 49.

${ }^{53}$ See, e.g., SaUl D. Alinsky, Rules for Radicals: A Practical Primer for

REALISTIC RADICALS (1971); see also infra notes 91-92 and accompanying text.

${ }^{54}$ Christine B. Harrington, Community Organizing Through Conflict Resolution, in THE POSSIBILITY OF POPULAR JUSTICE, supra note 43, at 401, 422, 429.

55 Thomson \& DuBow, supra note 52, at 169, 197.

56 Yngvesson, supra note 49, at 382.

57 Id. at 381, 397-99.

58 See, e.g., Carrie Menkel-Meadow, Pursuing Settlement in an Adversary Culture: $A$ Tale of Innovation Co-opted or "The Law of ADR," 19 FLA. ST. U. L. REV. 1, 1-3 (1991) (arguing that the legal establishment's use of ADR to manage caseloads and increase efficiency co-opted a competing vision of ADR as an innovative or transformative movement); Nancy A. Welsh, The Place of Court-Connected Mediation in a Democratic Justice System, 5 CARDozo J. Conflict Resol. 117, 138-39 (2004) ("In sum, courtconnected mediation has evolved from a process that focused on enhancing individual citizens' voice, control and assurance of accountability into a mechanism that resolves cases by reconciling these citizens to the institutional reality... of the courts and litigation."). 
of privatization and contract ideology in the case of court-annexed mediation. Indeed, opponents of mediation vocally argued that rather than returning the authority to "the people themselves" (here the parties to the dispute), mediation reproduced social inequalities and contributed to the erosion of public valuesplacing it far afield from the contemporary progressive constitutionalism vision. ${ }^{59}$

Although this transformation from a model of democratic empowerment to a model of governance and service delivery-with all its contradictions and inequalities-was certainly shaped by the particular cultural and historical context in which it emerged, it was not inevitable or necessary. There are many examples, both historical and contemporary, of mediation forums that function as places where collectives-women, squatters, tenants-advocate publicly on behalf of their interests and rights. ${ }^{60}$ Mediation's failure in the United States to follow a similar trajectory made it utterly disappointing to left critics who hoped that community mediation programs would provide "a public forum for questioning the foundations of the legal system" that could "lead to expansion of extralegal methods of protest and organization of the community around

${ }^{59}$ For a sampling of such criticisms, see, for example, Penelope E. Bryan, Killing Us Softly: Divorce Mediation and the Politics of Power, 40 BUFF. L. REV. 441 (1992); Richard Delgado, ADR and the Dispossessed: Recent Books About the Deformalization Movement, 13 LAw \& Soc. INQUIRY 145 (1988); Richard Delgado et al., Fairness and Formality: Minimizing the Risk of Prejudice in Alternative Dispute Resolution, 1985 WIS. L. REV. 1359; Harry T. Edwards, Alternative Dispute Resolution: Panacea or Anathema?, 99 HARV. L. ReV. 668 (1986); Owen M. Fiss, Against Settlement, 93 YALE L.J. 1073 (1984); Trina Grillo, The Mediation Alternative: Process Dangers for Women, 100 YALE L.J. 1545 (1991); Michele G. Hermann, The Dangers of ADR: A Three-Tiered System of Justice, 3 J. CONTEMP. LEGAL IsSUES 117 (1989-1990); Jana B. Singer, The Privatization of Family Law, 1992 WIS. L. REV. 1443.

${ }^{60}$ Consider Richard Abel's volume, 2 THE POLITICS OF INFORMAL JusticE: COMPARATIVE STUdIES (Richard Abel ed., 1982), which includes detailed sociological essays illustrating how in several countries extrajudicial dispute resolution contributed to mobilizing collective action on behalf of workers, peasants, urban squatters and women during, for example, the 1974-1975 Portuguese revolution, see Boaventura de Sousa Santos, Law and Revolution in Portugal: The Experiences of Popular Justice After the 25th of April 1974, 2 THE POLITICS OF INFORMAL JUSTICE, supra, at 251, the Mozambican war to achieve independence from Portugal, see Barbara Isaacman \& Allen Isaacman, A Socialist Legal System in the Making: Mozambique Before and After Independence, 2 THE POLITICS OF INFORMAL JUSTICE, supra, at 281, and the Allende years in Chile, see Jack Spence, Institutionalizing Neighborhood Courts: Two Chilean Experiences, 2 THE POLITICS OF INFORMAL JUSTICE, supra, at 215. Cohen's more recent ethnographic work in Nepal examines how donor-funded NGOs used U.S.-style mediation to criticize the state and hold it accountable to popular demands. Amy J. Cohen, Debating the Globalization of U.S. Mediation: Power, Practice, and Politics in Nepal, 11 HARV. NEGOT. L. REV. 295, 297, $337-$ 51 (2006). 
collective interests." 61 But significantly, this transformation is also what made mediation a sustainable, firmly institutionalized, and, from the perspective of its practitioners, apolitical part of conventional legal practice, even as-or as we suggest in the Part that follows, precisely because-it promised an alternative mode of engagement with law and legal rules.

\section{THE LAWS OF ALTERNATIVES}

In this Part we venture to explain how, in the United States, mediation scholars and practitioners fashioned mediation's populist, anti-authoritarian, bottom-up impulses into a conventional institutionalized practice that is today a fixture of the American legal system. We propose that basic to the antiauthoritarian impulse in ADR are five internal principles or what we call "laws of alternatives." We suggestively call these principles "laws" because, as Alberstein has observed elsewhere, they repeat consistently and predictably in other similar kinds of alternative legal reform movements, such as therapeutic jurisprudence and restorative and transitional justice. ${ }^{62}$ And although in this Article we use mediation as our sole example of an entrenched, institutionalized alternative legal practice, we refer more broadly to the laws of "alternatives" (rather than of mediation) because they cut across multiple legal reform movements.

These laws or principles embody alternatives' own particular democratic promise. They are intended to provide a means for individuals to engage, in an anti-authoritarian manner, in bottom-up acts of social-legal problem solving. And despite the sobering historical trajectory that we outlined above, they continue to inspire scholars and practitioners to articulate a renewed faith in the progressive, democratic, and empowering possibilities of ADR. ${ }^{63}$ Based on our experience teaching, practicing, and studying alternatives, we thus suggest that

${ }^{61}$ Richard Hofrichter, Neighborhood Justice and the Social Control Problems of American Capitalism: A Perspective, in 1 THE POLITICS OF INFORMAL JustiCE, supra note 31 , at $207,243$.

62 Michal Alberstein, ADR and Transitional Justice as Reconstructing the Rule of Law, 2011 J. DISP. RESOL. 127, 130-42.

${ }^{63}$ See, e.g., Mariana Hernandez Crespo, Building the Latin America We Want: Supplementing Representative Democracies with Consensus-Building, 10 CARDOZO J. CONFLICT RESOL. 425 (2009); Nancy D. Erbe, Appreciating Mediation's Global Role in Promoting Good Governance, 11 HARV. NEGOT. L. REV. 355 (2006); Michael Hamilton \& Dominic Bryan, Deepening Democracy? Dispute System Design and the Mediation of Contested Parades in Northern Ireland, 22 OHIO ST. J. ON DISP. RESOL. 133 (2006); Carrie Menkel-Meadow, The Lawyer's Role(s) in Deliberative Democracy, 5 NEV. L.J. 347, 34849 (2004); Jeffrey R. Seul, Settling Significant Cases, 79 WASH. L. REV. 881 (2004); Lawrence E. Susskind, Keynote Address, Consensus Building, Public Dispute Resolution, and Social Justice, 35 FORDHAM URB. L.J. 185, 190-91 (2008); Alex Wellington, Taking Codes of Ethics Seriously: Alternative Dispute Resolution and Reconstitutive Liberalism, 12 CAN. J.L. \& JURIS. 297 (1999). 
the laws of alternatives offer a unique and seductive language, a set of professional attitudes, and modes of conflict intervention that have deepened over time in numerous practice-oriented legal reform movements, even if they have not penetrated more conventional and theoretical legal scholarship.

At the same time, however, the history of U.S. ADR is a cautionary tale for progressive social movements and these principles also help to explain how mediation became congruent with conventional legal-bureaucratic institutions that are purposely depoliticized and non-radical. The laws of alternatives offer rather specific ways to teach ordinary people how to engage with legal and political questions as relational, reasonable, pragmatic actors. They aim to produce manageable, collaborative, consensus-seeking subjects who are therefore entitled to engage in their own acts of socio-legal ordering without explicit direction from above. We briefly describe some of their constitutive elements so that we can assess, in the following Part, how they might inform the field of progressive constitutionalism.

The first law that virtually all alternative movements share in common is a pragmatic commitment to process as a means of overcoming and evading substantive conflict. In the face of moral difference, alternatives aspire to enable collective decision making by offering a set of procedural ideals that all parties can agree to embrace regardless of their ideological orientation, class positions, or substantive disagreement. This emphasis on process is sometimes described as a second-order negotiation. ${ }^{64}$ As Roger Fisher and William Ury explain it, negotiating a decision-making and dispute resolution process enables parties to decide how to "negotiate the substantive question." 65 In fact, for many scholars of alternatives, reaching the correct decision about process - what is commonly called "procedural justice" - often matters more than substantive outcomes. ${ }^{66}$ This emphasis on process is also a core principle of American pragmatism. Rather than decide between substantive dichotomies such as mind and body, empiricism and rationalism/reason, or being or not being, the philosophy of American pragmatism adopts a constant processual shift toward "becoming."67

${ }^{64}$ See Roger Fisher \& William URy, GetTing to Yes: Negotiating AgreEmEnT WITHOUT GIVING IN 10 (Bruce Patton ed., 1983).

65 Id. In their words: "The second negotiation concerns how you will negotiate the substantive question: by soft positional bargaining, by hard positional bargaining, or by some other method. This second negotiation is a game about a game-a "meta game." Id.

${ }^{66}$ For an overview of procedural justice, see generally E. ALLAN LIND \& TOM R. TYLER, THE SOCIAL PSYCHOLOGY OF PROCEDURAL JUSTICE (1988). For an exploration of the relevance of this notion for negotiation and mediation, see generally Rebecca HollanderBlumoff \& Tom R. Tyler, Procedural Justice in Negotiation: Procedural Fairness, Outcome Acceptance, and Integrative Potential, 33 LAW \& SOC. INQUIRY 473 (2008); Nancy A. Welsh, Making Deals in Court-Connected Mediation: What's Justice Got to Do With It?, 79 WASH. U. L.Q. 787 (2001).

67 For an overview of pragmatism, see generally CLASSICAL AMERICAN PRAGMATISM: ITS CONTEMPORARY VITALITY (Sandra B. Rosenthal et al. eds., 1999); MATTHEW Festenstein, Pragmatism and Political Theory: From Dewey to RorTy (1997); 
This shift substitutes experience for metaphysics: instead of searching for an overarching truth that explains reality (a truth that is above physics, i.e., "meta" physics), pragmatism considers the sensual experience of the world, including the experience of thought, as the only foundation of any truth. ${ }^{68}$ Likewise, practitioners of alternatives stress that conflict has no "real" foundation that intrinsically defies a potential rearticulation. ${ }^{69}$ Rather the experience of conflict is here and now and thus can be reconfigured and reframed in new terms through the right dialogic process. ${ }^{70}$ Parties that participate in alternative legal movements are therefore encouraged to defer judgment on specific substantive questions. The idea is that through the actual experience of participating in a structured process, individuals and groups are more likely to integrate their

Pragmatism: A Reader (Louis Menand ed., 1997); Pragmatism: From Progressivism to Postmodernism (Robert Hollinger \& David Depew eds., 1995); THE Revival OF Pragmatism: New Essays on Social Thought, LaW, AND Culture (Morris Dickstein ed., 1998). For the relation between the philosophy of pragmatism and the emphasis on process and overcoming dichotomies, see Michal Alberstein, Pragmatism and LaW: From PHILOSOPHY TO DISPUTE RESOLUTION 1-99 (2002).

68 See, e.g., JoHN DEWEY, RECONSTRUCTION IN PhILOSOPHY 91-181 (1920); JOHN DEWEY, EXPERIENCE AND NATURE 40-77 (1926); William James, What Pragmatism Means, in PragmatisM, supra note 67, at 93-111. But compare Hilary Putnam, Pragmatism and Realism, in THE ReVIVAL OF PRAGMATISM, supra note 67, at 37-53.

${ }^{69}$ See, e.g., FISHER \& URY, supra note 64, at 23 (defining truth as an "argumentperhaps a good one, perhaps not-for dealing with ... difference"); DOUGLAS STONE, Bruce Patton \& Sheila Heen, Difficult Conversations: How to Discuss What MATTERS MOST 118, 132 (1999) ("The bottom line is that there is no bottom line." And "the truth is, there is no 'right choice.' There is no way to know in advance how things will really turn out. So don't spend your time looking for the one right answer about what to do. It's not only a useless standard, it's crippling."); Nancy Welsh, Perceptions of Fairness, in THE NEGOTIATOR'S FIELDBOOK: THE DESK REFERENCE FOR THE EXPERIENCED NEGOTIATOR 165, 171 (Andrea Kupfer Schneider \& Christopher Honeyman eds., 2006) ("[F]airness . . is largely a matter of perception.").

${ }^{70}$ See, e.g., Jonathan G. Shatlor, EMPOWERMENT in Dispute MEdiation: A CRITICAL ANALYSIS OF COMMUNICATION 18-31 (1994) (offering a constructivist and communication-based based theory of conflict and a corresponding theory of mediation that invites disputants to transform their discursive practices and hence their "forms of life"); JohN Winslade \& Gerald MONK, NarRative MEdiation: A New Approach to CONFLICT RESOLUTION 52-53 (2000) (offering a theory of conflict as socially constructed, context-dependent, and grounded in narratives and perceptions: "when a conflict story takes root, it generates a momentum that does not reflect the facts or realities of a situation because stories mediate our knowledge of reality. .. . It follows, then, that the success of a mediation might depend ... on the extent to which the mediator can work with the parties to create an alternative story."); Sara Cobb, Empowerment and Mediation: A Narrative Perspective, 9 NEGOT. J. 245, 255 (1993) (arguing that "mediation is social construction (and not a process based on 'real needs and interests')," and that mediators can therefore use discursive techniques to destabilize existing narratives and enable parties to create new nonadversarial ones). 
differences and ideological oppositions and, indeed, to transform and reconstruct their own conflicts.

The second related law is constructive future-oriented intervention. A pragmatic commitment to process embodies its own unique bias-namely, the optimistic assertion that through designing the right process, better solutions and improved relationships are always possible. Thus, rather than encourage disputants simply to adjudicate the rightness or wrongness of their claims through the application of fixed and retrospective legal rules, alternatives instead aim to cultivate open-ended processes that present conflict as an opportunity for growth, creativity, and change and that prioritize future-oriented normative arguments. This orientation equally discourages truth claims and nihilism: instead, it asks people how they think they ought to arrange their affairs and solve their problems going forward, and it encourages them jointly to construct their own willful picture of reality. ${ }^{71}$

As a strategy for action to move disputants away from backward-looking ideological assertions and towards a constructive future orientation, the third law is what we call deconstruction and hybridization. In brief, facilitators of alternatives encourage disputants to deconstruct an "all or nothing" or "winlose" legal framework into a multiple array of smaller more manageable problems, interests, choices, preferences, and desires. ${ }^{72}$ These problems, in turn, become partly resolvable through hybridization-that is, a creative strategy for practical bargaining and compromise in which parties agree to make

${ }^{71}$ For a few examples, see BUSH \& FOLGER, supra note 36 , at $81-112$ (theorizing conflict as a positive opportunity for new moral growth); CARRIE J. MENKEL-MEADOW ET AL., DisPuTE RESOlution: BEYOND THE AdVERSARIAL MODEL 12-20 (2005) (presenting excerpts on constructive conflict resolution that challenge adversarial win/lose models); STONE ET AL., supra note 69 (providing guidelines to transform disputes grounded in facts, emotions, and identities into constructive conversations); Carrie Menkel-Meadow, Mothers and Fathers of Invention: The Intellectual Founders of ADR, 16 OHIO ST. J. ON DISP. RESOL. 1, 6-10 (2000) (presenting constructive and creative notions of conflict as one of the core ideas that inspired the development of the ADR movement).

72 Robert Axelrod's game-theoretic work on the prisoner's dilemma provides the basis for a famous deconstruction of this sort. He assumes a recurring, rather than one-shot, prisoner's dilemma, which enables each player to engage in a series of discrete, small responses to her opponent's choices. Axelrod then proceeds to show how particular kinds of responses can develop rational incentives for collaboration over the course of the longer game. ROBERT AXELROD, THE EVOLUTION OF COOPERATION 27-54 (1984). Drawing on Axelrod, theorists of alternatives likewise describe the act of negotiating conflict not as a one-shot deal but rather as a series of choices or stages where parties can make small decisions to establish a growing sense of trust and collaboration. See, e.g., DAVID A. LAX \&

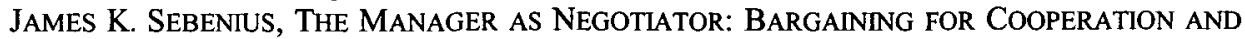
COMPETITIVE GAIN 160 (1986) (using Axelrod's research to propose dividing the negotiation "process into a number of small steps"); see also Roger Fisher, Fractionating Conflict, 93 DAEDALUS 920, 921 (1964) (similarly proposing a number of practical advantages for conflict resolution when major conflicts are treated as "a number of small ones"). 
incremental and piecemeal trades across multiple divergent interests and desires. ${ }^{73}$

Deconstruction and hybridization also encourage disputants to doubt and interrogate their own understandings of conflict-or at least the understandings of conflict that they initially self-present. We thus call the fourth law the search for an underlying hidden layer. This hidden layer is variously described by theorists and practitioners as interests, needs, or narratives of entitlement. If on the surface, conflict is antagonistic and distributive, parties who can deconstruct and self-identify the "hidden layer" underlying their conflict can reframe their disputes in ways that are more rational. For example, if parties can express the putative interests and needs that are driving their positions, they can both create and expand the benefits of trade. Likewise, if parties can articulate and critically interrogate their own desires and narratives of self-entitlement--what they want and why they want and think they deserve it - they are more likely to explain and/or modify their positions in ways that make their motivations appear more persuasive and equitable to others. Ideally, through these dialogic exercises of explanation, rationalization, and change, parties develop common understandings of reason that inform how they will resolve their disputes. ${ }^{74}$

Finally, alongside this search for the underlying layer of conflict, alternatives stress the acknowledgment of emotions and simultaneously depersonalization-our fifth law. Alternatives characteristically offer a reconstructed vision of the juridical subject that emphasizes the relational aspects of disputes. ${ }^{75}$ By acknowledging emotions as a significant element in human disputes, parties are taught to understand themselves as less individualistic, less separated, less rule-bound and more caring and empathic. But although parties are encouraged to reframe legal and economic disputes as, in part, reflections of the complex affective dynamics and feelings that occur in

${ }^{73}$ For a few examples, see FISHER \& URY, supra note 64, at 73-79 (describing how to use shared and differing interests to "invent options for mutual gain"); LAX \& SEBENIUS, supra note 72, at 88-116 (offering lessons in "trading on difference"); ROBERT H. MNOOKIN, SCOTT R. PEPPET \& ANDREW S. TUlumello, BEYOND WINNING: NEGOTIATING TO CREATE VALUE IN DEALS AND DisPUTES 12-15, 28-43 (2000) (offering lessons in how to identify the multiple issues comprising a problem and to leverage differing issues into value creating trades).

${ }^{74}$ For examples, see FISHER \& URY, supra note 64, at 41-57 (chapter on "[f]ocus[ing] on [i]nterests"); WINSLADE \& MONK, supra note 70, at 94-115 (chapter on needs and entitlements and "how narrative mediation can be used to deconstruct entitlements in an attempt to assist people to build more equitable relations when conflict is being addressed"); Carrie Menkel-Meadow, Toward Another View of Legal Negotiation: The Structure of Problem Solving, 31 UCLA L. REV. 754, 801-17 (1984) (sections on "identifying the parties' underlying needs and objectives" and "creating solutions").

${ }^{75}$ See, e.g., Deborah M. Kolb, The Love for Three Oranges Or: What Did We Miss About Ms. Follett in the Library?, 11 NEGOT. J. 339, 344 (1995) (arguing that "a significant component of the negotiation process is the creation of a frame of connectedness within which negotiations can take place"). 
the interstices of social relations, they are simultaneously (if somewhat paradoxically) encouraged to depersonalize their differences. Disputants are encouraged to transform themselves from agonistic individuals to joint problem-solving units tasked with generating common proposals for conflict resolution..$^{76}$ The idea is that emotions have a logic of their own; when they are acknowledged and expressed, disputants understand the conflict differently and become better able jointly to focus their energy on the problem, not the people. ${ }^{77}$

Through each of these five "laws" or principles-which are administered and reproduced through intensive training and skilled facilitation-alternatives like mediation seek to shape how individuals and groups engage legitimately in democratic acts of social and legal problem solving. Of course, none of these techniques are neutral constructs nor are they innocent of power and distributional effects. In her work, Cohen has analyzed the kinds of uneven and regressive outcomes they may produce under conditions of inequality. ${ }^{78}$ But to return to our description of the progressive and anti-authoritarian impulses underlying early $\mathrm{ADR}$, the point we wish to make here is that alternative movements in law embody a particular set of ideals and practices that govern how ordinary people should transform themselves into social-legal problem solvers. Lay actors are trained to participate in the resolution of legal conflict by willingly adopting shared commitments to constructive, forward-looking, pragmatic processes and by learning to doubt and deconstruct social conflict in ways that generate spaces for new understandings and dialogic exchange. Thus, as a prescriptive institutional project designed to spawn not only dispute resolution but also democratic self-governance, ${ }^{79}$ alternatives like mediation suggest that it does not suffice to envision a new democratic juridical subject. Far more actively, one must aim to create this subject and endow her with a particular set of practices and techniques that shape how she engages in the creation of social and legal organization. The laws of alternatives are a set of shorthand principles that aim to capture how a group of theorists and practitioners approach the highly normative task of transforming a general, even

76 To achieve this end, Fisher and Ury, for example, suggest that parties jointly adopt principled problem-solving criteria as a depersonalized choice-making procedure. FISHER \& URY, supra note 64, at 84-98.

77 Id. at 56. For examples, see ROGER Fisher \& DANIEL SHAPIRO, BEYOND REASON: USING EMOTIONS AS You Negotiate 15 (2005); STONE ET AL., supra note 69, at 85-108 (chapter on emotions: "Have Your Feelings (Or They Will Have You)"); Daniel L. Shapiro, Emotions in Negotiation: Peril or Promise? 87 MARQ. L. REV. 737 (2004); Daniel. L. Shapiro, Negotiating Emotions, 20 CONFLICT RESOL. Q. 67 (2002).

78 See generally Amy J. Cohen, Negotiation, Meet New Governance: Interests, Skills, and Selves, 33 LAW \& SOC. INQUIRY 503 (2008). We should add that many of the proponents of these principles have also critically analyzed their limitations in various conflicts and contexts.

${ }^{79}$ For recent and quite popular revival of this early ADR ideal, see supra note 63. 
inchoate, desire for democratic empowerment into a set of regularized (and manageable) social conventions that govern how lay actors should participate in bottom-up processes of norm generation and lawmaking.

To return now to progressive constitutionalism, the question we explore in the following Part is whether a similar sort of subject underlies its antiauthoritarian vision. To be sure, all forms of democratic governance involve efforts to shape human conduct-not by means of obvious coercion or control, but often more subtly, although no less powerfully, through what Barbara Cruikshank calls the "will to empower" or "work[ing] upon the capacities of citizens to act on their own behalf." 80 Who, then, do proponents of extrajudicial constitutional governance envision when they describe active, self-empowered lay participants in constitutional interpretation? At minimum, these are people who, to summarize Larry Kramer, feel entitled to disagree with judicial rulings and to act on their disagreement. ${ }^{81}$ The salient inquiry, however, is not simply how subjects come to feel entitled to disagree but what they understand as legitimate strategies for action.

\section{QUESTIONS FOR PROGRESSIVE CONSTITUTIONALISM: POPULAR DEBATES ABOUT HEALTH CARE REFORM}

Theorists of extrajudicial constitutionalism offer us fascinating accounts of how nonjudicial actors, at different periods of American history, claim power to articulate their own constitutional visions. These accounts, which are often historical rather than conceptual or prescriptive, productively challenge conventional understandings of law as an instrument of social order produced from above. ${ }^{82}$ At present, this richly descriptive scholarship stands apart from comparisons to alternative legal reform movements in law.

That said, we are also mindful of the number of commentators who have demanded, in prescriptive institutional fashion, to know how extrajudicial strands of constitutional lawmaking can and should work in the present to translate popular will into legal and policy formulations. For example, David Pozen recently argued that although significant attention "has been devoted to popular constitutionalism as a theoretical project, hardly any attention has been paid to questions of institutional design.... Those who have championed

${ }^{80}$ Barbara Cruikshank, The Will to EmPOWER: Democratic CitIZENS ANd OTHER SUBJECTS 1, 39 (1999).

${ }^{81}$ See supra note 21 and accompanying text.

${ }^{82}$ See generally KRAMER, THE PeOPLe Themselves, supra note 2 ; KeITH E. WhitTIngton, Constitutional Construction: Divided PowERS AND CONSTITUTIONAL MEANING (1999); James Gray Pope, Labor's Constitution of Freedom, 106 YALE L.J. 941 (1997); Reva B. Siegel, Constitutional Culture, Social Movement Conflict and Constitutional Change: The Case of the De Facto ERA, 94 CALIF. L. Rev. 1323 (2006); Reva B. Siegel, Dead or Alive: Originalism as Popular Constitutionalism in Heller, 122 HARV. L. REV. 191 (2008). 
popular constitutionalism... 'have said very little about the particular institutional mechanisms that would make their vision a reality in today's world." 83 Indeed, although a core idea of extrajudicial constitutionalism is that we must all have meaningful opportunities to criticize and revise the laws that constrain us, the field has largely left unanswered (or at least left ambiguous) the question of precisely what kinds of direct participatory acts should count as acts of constitutional interpretation. Spindelman, for example, calls for political deliberations informed by "an active sense of constitutional fidelity, duty, and purpose." ${ }^{4}$ Todd Pettys likewise ventures that there are "good reasons to believe that the American people possess the powers of deliberation and restraint necessary to honor the distinction that constitutionalism requires between their long-term fundamental commitments and their short-term political desires." 85 But what should these deliberations look like in practice and what kinds of lay participation in constitutional interpretation would elite legal scholars and practitioners recognize as efficacious, principled, and thus valid political-legal action?86

Alternative movements in law would answer this question in a particular normative way-namely, through their jurisprudence of conflict resolution and conflict management. This jurisprudence would propose to deconstruct and reconstruct popular constitutional questions by, for example, encouraging

83 Pozen, supra note 4, at 2049 (citation omitted); see also David L. Franklin, Popular Constitutionalism as Presidential Constitutionalism?, 81 CHI.-KENT L. REV 1069, 1075 (2006) ("How, exactly," he asks, "are we [the people] supposed to exercise ... authority" over constitutional interpretation?); Pettys, supra note 2, at 321 ("By what means are the American people expected to exercise their interpretive power?"); Suzanna Sherry, Putting the Law Back in Constitutional Law, 25 CONST. COMMENT. 461, 463 (2009) (arguing that "few (if any)" theorists offer "concrete suggestions about how to implement popular constitutional interpretation"). We should note that scholars of legislative constitutionalism have offered institutional proposals and principles to shift constitutional interpretation from courts to Congress. For one example, see TUSHNET, supra note 5, at 111-57 (presenting case studies of congressional and parliamentary constitutional decision making that include comparative features of institutional design). Still, as the analysts quoted here note, scholars of extrajudicial constitutionalism have in general said less "about what their theories demand from individual citizens in order to operate effectively." Doni Gewirtzman, Glory Days: Popular Constitutionalism, Nostalgia, and the True Nature of Constitutional Culture, 93 GEO. L.J. 897, 910 (2005).

${ }^{84}$ Spindelman, supra note 1 , at 1116.

85 Pettys, supra note 2, at 344 .

${ }^{86} \mathrm{~A}$ related question, that we do not address, is framed by Mark Tushnet: "what counts as advancing a constitutional value." Tushnet, supra note 6, at 1003 (emphasis added). For example, Tushnet suggests that one could "believe that the U.S. Constitution commits the nation to guaranteeing income security for all even though that position has little purchase in contemporary adjudicated constitutional law." Id. at 1003-04; see also Franklin, supra note 83, at 1074 (proposing that in an extrajudicial constitutional regime "many things we are used to thinking of as questions of ordinary law or policy turn out to be constitutional questions"). 
stakeholders to doubt their own presentation of a given conflict as an irreconcilable clash of rights, laboring to break the conflict into smaller composite questions, constructing open-ended processes to engage with these questions and, ideally, transforming them into problem-solving ventures. Indeed, alternative movements in law would frame interpersonal collaboration and communication as its own public and progressive good. ${ }^{87}$ Progressive constitutionalists, however, may or may not desire to adopt a similar set of ideals and techniques, depending on their understanding of how constitutional politics do and should operate on the ground.

To illustrate our point, consider an actual example of extrajudicial constitutionalism that bridges alternative dispute resolution theory and popular (although hardly left progressive) legal/political action. In the summer and fall of 2009, U.S. government officials hosted town hall meetings to stimulate popular discussion about proposed federal health care legislation. Just as extrajudicial constitutionalism envisions, these events called for popular political engagement with national questions of social-legal ordering, not professional arguments before courts. And, indeed, these meetings were populated by ordinary people —often Tea Party activists-who organized (from above and below ${ }^{88}$ ) to express their views about whether the proposed bill advanced or undermined American constitutional values, as they understood them. The Tea Party, which emerged as a political force in 2009 , is united by its opposition to particular kinds of government spending (reflected, for example, in its opposition to the stimulus and health care bills) and its general claim that the federal government has surpassed the constitutional limits on its powers. ${ }^{89}$ As such, several legal scholars have described it as its own extrajudicial constitutional movement. 90

${ }^{87}$ In this sense, alternative movements recall the progressive political ideals of John Dewey. See, e.g., John Dewey, The Public AND ITS Problems 142, 184, 211 (1927) (arguing for the foundational role of "communication" in producing publics and political community).

${ }^{88}$ See, e.g., Kate Zernike, Bolling MAD: InSIDE TEA Party America 4-6 (2010) (emphasizing the extent of grassroots participation in the Tea Party movement despite its support and funding from large interest groups and wealthy individuals).

${ }^{89}$ See Randy Bamett, The Tea Party, the Constitution, and the Repeal Amendment, 105 Nw. U. L. REV. COLLOQUY 281, 282 (2011), http://www.law.northwestern.edu/lawreview/ colloquy/2011/10/LRColl2011n10Barnett.pdf. For a general overview of some Tea Party principles (including opposition to "government-run health care"), see CONTRACT FROM AMERICA, http://www.thecontract.org/the-contract-from-america/ (last visited Sept. 23, 2010); see also JOHN M. O'HARA, A NEW AMERICAN TEA PARTY: THE Counterrevolution against Bailouts, Handouts, Reckless Spending, and More TAXES 206-08 (2010) ("Who They Are and What They Believe").

${ }^{90}$ See, e.g., Jared A. Goldstein, Can Popular Constitutionalism Survive the Tea Party Movement, 105 Nw. U. L. REV. COLloquY 288, 288-89 (2011), http:// www.law.northwestern.edu/lawreview/colloquy/2011/11/LRColl201 ln1 1Goldstein.pdf; Ilya Somin, The Tea Party Movement and Popular Constitutionalism, 105 Nw. U. L. REV. 
Rather than feature the idealized constructive dialogue that the laws of alternative would hope to inspire, actual town hall meetings were dominated by right-wing organizers who encouraged activists to model their strategies after, in the words of one Tea Party activist, "the Alinsky playbook of which the Left is so fond: freeze it, attack it, personalize it, and polarize it." 91 Like theorists of extrajudicial constitutionalism and extrajudicial dispute resolution, Alinsky called for bottom-up empowerment as an antidote to citizen passivity. He desired to create an alternative mode of political engagement in response to "the vast mass of our people who, thwarted through lack of interest or opportunity, or both, do not participate in the endless responsibilities of citizenship and are resigned to lives determined by others." 92 Alinsky, however, hoped to produce what he called radical pragmatists-that is, activists willing to act within the existing system but in order to "speak out and denounce the administration, attack its policies, [and] work to build an opposition political base."93 True to Alinsky's organizing vision, Connecticut Tea Party organizer, Bob MacGuffie, announced that his objective at town hall meetings was "to 'pack the hall' with as many of our people ready to challenge the Congressman, put him on the defensive, and give him a reality check from we-the-people." 94 To that end, MacGuffie proffered the following organizing techniques: "put the Rep on the defensive with your questions and follow-up"; "[w]atch for an opportunity to yell out and challenge the Rep's statements early"; "set the tone for the hall as clearly informal and free-wheeling." 95 Conservative activists thus aimed quite methodically to demonstrate their opposition to proposed legislation through obstructionist modes of engagement that were highly personalized, nondialogic, and that retrenched the conflict as antagonistic, all-or-nothing, and

COLLOQUY 300, 302-04 (2011), http://www.law.northwestern.edu/lawreview/colloquy/ 2011/12/LRColl2011n12Somin.pdf.

${ }^{91}$ Robert MacGuffie, Rocking the Town Halls--Best Practices 1-3, available at $\mathrm{http}$ //talkingpointsmemo.com/documents/2009/08/memo-details-co-ordinated-anti-reformharrassment-strategy.php?page $=1$, quoted in Carrie Menkel-Meadow, Scaling Up Deliberative Democracy as Dispute Resolution in Healthcare Reform: A Work in Progress, 74 LAW \& CONTEMP. PROBS. 1, 15 (2011); see also ZERNIKE, supra note 87, at 3 (quoting a Tea Party organizer rallying a crowd from a podium: "I say, let's read Saul Alinsky, let's read Rules for Radicals, and let's use it against them!").

${ }^{92}$ ALINSKY, supra note 53, at xxv-xxvi. Alinsky, in fact, opens his book with a cautionary narrative about acquiescence to judicial authority, even under circumstances that appear radical. When a group of lawyers entered the lobby of a federal courthouse to protest the trial of the Chicago Seven, they were confronted by the presiding judge, William Campbell. Campbell announced his intention to hold court in the lobby in order to find the lawyers in contempt. After a protester shouted, "Fuck you, Campbell," the judge retreated. To Alinsky's dismay, when the judge retreated the lawyers left the building and, in his analysis, "let the initiative pass from them to the judge, and achieved nothing." Id. at 6.

${ }^{93}$ Id. at $\mathrm{xxi}$.

${ }^{94}$ MacGuffie, supra note 91 , at 1.

${ }^{95} \mathrm{Id}$. at 2. 
hostile to compromise. To fight and influence a popular social-political struggle, these activists thus claimed power to define the problem at hand by purposefully refusing to cultivate desires for self-skepticism, critical deconstruction, joint inquiry, or inclusive procedural commitments.

Reflecting on these meetings from an alternative jurisprudential perspective, Carrie Menkel-Meadow endeavored to diagnose "what went wrong."96 Although she does not frame her analysis in these terms, she proposes that these meetings-and the theories of democratic deliberation that underlie and support them-failed to adopt and enforce any of the laws of alternatives. Most especially, Menkel-Meadow suggests that they failed to implement principles of engagement that correspond to what we would call "the search for the underlying hidden layer," "deconstruction and hybridization," and "acknowledgement of emotion/depersonalization." In her words:

At its core, my argument is that naïve political and philosophical theories about the use of "reason" in democratic deliberation fail to take adequate account of two other major modes of modern discourse: bargaining and affective (involving emotion and ethical, religious, or strongly held values) or feelingbased arguments. If dispute resolution techniques based on ADR principles of focusing on parties' needs, interests and underlying values are to be used for major policy decisions aiming to increase polity participation in decisions affecting the lives of all, then those techniques (and the theories on which they are based) may require some adaptation to large-scale moments of deliberation and decision making. ${ }^{97}$

In this quotation, Menkel-Meadow contends that architects of democratic deliberation (including of town hall meetings) often misunderstand the roles that bargaining (i.e., "deconstruction and hybridization"), emotion, and underlying values and interests do and should play in disputing and dispute resolution. With this argument, she challenges theorists and practitioners of both deliberative democracy and dispute resolution critically to consider how they could adapt ADR principles and techniques to large-scale disputes about conflictual political, legal, and, here, potentially constitutional issues.

To be sure, adapting principles from alternative dispute resolution to political deliberation is a complex, if burgeoning, field. ${ }^{98}$ Unlike the parties to

${ }^{96}$ Menkel-Meadow, supra note 91 , at 3.

${ }^{97}$ Id. (emphasis omitted).

${ }^{98} \mathrm{See}$, e.g., id. at 18 . Indeed, two new legal textbooks are devoted to the topic of designing systems to resolve larger-scale conflict. See LISA BLOMGREN BINGHAM, JANET Martinez \& StePhanie Smith, Dispute Systems Design: Preventing, Managing, and RESOLVING CONFLICT (forthcoming 2012); NANCY H. ROGERS, ROBERT C. BORDONE, FRANK E.A. Sander \& Craig A. McEwen, Designing Systems and Creating Processes for THE EFFECTIVE MANAGEMENT OF CONFLICT (forthcoming 2012). For other important contributions to the field of public dispute resolution, see generally SUSAN L. CARPENTER \& W.J.D. Kennedy, Managing Public Disputes: A Practical Guide for Government, 
small-scale private disputes, interested stakeholders engaged in large-scale political deliberation are themselves often not decision makers and typically include not only individuals but also collective private and public entities (e.g., corporations, municipalities, and states). Moreover, all these parties negotiate less in the shadow of clearly enforceable legal defaults than of their own moral, political, and material commitments. ${ }^{99}$ At minimum however, Menkel-Meadow proposed that the town hall meetings to discuss health care legislation needed better design and much more purposeful management - that is, they needed "an experienced moderator or facilitator present to manage and skillfully shape the conversation in a productive way."100

As we will suggest below, facilitated dialogue is not a straightforward or even necessarily desirable innovation for progressive constitutionalistsparticularly for those who wish to enhance opportunities for unconstrained political debate. Unlike scholars of alternatives such as Menkel-Meadow, who described specific town hall meetings as "procedural disasters," progressive constitutionalists might instead understand them as productive instances of ongoing political contestation surrounding health care. ${ }^{101}$ They might expect that such political contestation would happen through loosely structured diverse methods, and give rise to a complex series of interventions and counterinterventions that over time would shape popular political consciousness and formal institutional arrangements in political directions that are as of yet unclear. ${ }^{102}$

That said, as a matter of actual dialogic practice, a facilitator schooled in the law of alternatives would aim to restructure town hall meetings through a set of pragmatic procedural rules. These rules would typically include an agenda designed to organize and supervise the number of participants and the size and scope of topics for debate. For example, a facilitator could structure a series of smaller and larger group interactions. In smaller groups, she could use methods to try and move parties from backward-looking ideological assertions and deconstruct putatively zero-sum issues into smaller more manageable conversations with an eye towards enabling incremental trades and

Business, and Citizens' Groups (2d ed. 2001); The Consensus Building HandBook (Lawrence Susskind et al. eds., 1999); JOHN ForESTER, DEALING WITH DiffERENCES: DRAMAS OF MEDIATING PUBliC DisPUTES (2009).

99 These are only some of the differences that alternatives theorists and practitioners confront when they shift to larger-scale conflicts and contexts, and which we do not consider here. For an assessment of some of the political and distributional effects that may follow when designers apply ADR techniques to disputes that span multiple levels of scale, see Cohen, Dispute Systems Design, supra note 32.

${ }^{100}$ Menkel-Meadow, supra note 91 , at 16.

101 Id. at 23.

${ }^{102} \mathrm{Cf}$. Bruce ACKerman, 1 We the PeOple: Foundations 285-86 (1993) (emphasizing the value of long time horizons in formulating institutional responses to popular constitutional mobilization). 
compromises. These small-group discussions would, in turn, inform the larger debate. ${ }^{103} \mathrm{~A}$ facilitator could also try to instill an optimistic prospective orientation by calling for a commitment from everyone present to embrace certain norms of constructive collaboration. Indeed, from an idealized perspective of alternatives, if participants were willing to search for underlying hidden layers, acknowledge and express their own and others' emotions and needs, and depersonalize the conflict away from individual actors, perhaps they could transform the usual constitutional debate from distributive bargaining over scarce resources and one-sided ideological assertions into a more complex encounter among various needs and narratives. Progressivism would, in this vision, include the goal of common collaboration among the parties. Finally, if some of these tactics failed, facilitators would have methods to deal with difficult people-for instance, deflecting and diffusing personal attacks (Menkel-Meadow approvingly cites Senator Claire McCaskill's decision to accept only written, not oral, questions ${ }^{104}$ ), and they would retain the power, if necessary (albeit controversially), to screen and refuse to admit participants unwilling to abide by the required baseline norms. ${ }^{105}$

By contrast, in the actual meetings, "[t] $]$ here was little ground-rule setting, meeting management, conflict assessment, small-group discussion, or agendafollowing, which would have been present in more professionally managed large-group policy discussions." 106 Of course, numerous factors made public deliberations about health care extraordinarily complex. ${ }^{107}$ But from the perspective of alternatives, these meetings lacked a set of discursive institutional norms or ground rules that would serve as prerequisites for

${ }^{103}$ For examples, see Menkel-Meadow, supra note 91, at 22-24.

${ }^{104} \mathrm{Id}$. at 16-17 (also noting that McCaskill "remained calm and empathetic" and reported to the press that she did not interpret her opponents' attacks as personal assaults).

105 Id. at 25.

${ }^{106} \mathrm{Id}$. at 11. Dispute resolution scholar Larry Susskind offers a similar set of observations. "If the goal," he argues, of public participation in health care policy making

is to hammer out a consensus with regard to the district's views, it will be necessary to tap a professional mediator to undertake a district-wide conflict assessment that will produce a 'map' of all the relevant stakeholder groups vis a vis the health reform issue and to involve representatives of each of category of groups in formulating an agenda, ground rules, and a process of joint problem-solving.

Larry Susskind, How Should You Respond to the Noisy Health Reform Critics?, CONSENSUS BUILDING APPROACH (Aug. 11, 2009, 12:15 PM), $\mathrm{http}$ //theconsensusbuildingapproach.blogspot.com/2009/08/how-should-you-respond-tonoisy-health.html.

${ }^{107}$ As Menkel-Meadow notes, these debates often reflected political and social issues that exceed questions of health care reform, stakeholder groups were not only numerous but exceptionally diverse (representing disparate class, professional, and geographical positions), and the question of health care is itself particularly complicated. MenkelMeadow, supra note 91 , at 17-18, 20-22. 
engagement (and that the vast majority of people would agree to follow as a condition of their participation). And, perhaps more significantly, they lacked a team of trained facilitators tasked with organizing and educating willing subjects about how properly to engage politically with law outside of formally institutionalized forums. ${ }^{108}$ That is, these popular deliberations lacked a practical commitment to the vision of dialogue and skilled deliberation that the laws of alternatives aim to instill.

We do not mean to imply that a professionalized effort to administer a large-scale popular debate about a contentious political, legal, and constitutional question would have necessarily, or even likely, transformed passionate unruly activists into dutiful, collaborative problem solvers. As theorists of development and social change know well, ordinary people are remarkably resilient to professional efforts to remake them - either via rules of law or through other alternative law-like means. ${ }^{109}$ Our point instead is that practice-oriented alternative movements in law help to illuminate both the productive possibilities and also the normative limitations of more abstract or theoretical efforts to envision and endorse popular participation and bottom-up lawmaking from above. Alternative movements in law provide a means of enabling individuals to resolve disputes not through the imposition of substantive rules, but rather by developing particular problem-solving selves. Insofar as progressive constitutionalism aims to proliferate sites of constitutional interpretation from imposed judicial authority to popular deliberation, it could certainly desire an analogous end. But as Menkel-Meadow suggests, implementing popular engagement in large-scale and institutionalized acts of lawmaking requires a tremendous amount of facilitation and control by engaged professionals from above. ${ }^{110}$ Without these efforts, the discourse generated by social movements is

${ }^{108}$ See, e.g., id. at 22-25, 28. As Lynn Sanders rightly argues, this image of facilitation invokes expert technicians, indeed, classroom teachers. Lynn M. Sanders, Making Deliberation Cooler, Good Soc'Y, July 22, 2010, at 41, 42.

${ }^{109}$ See generally Amy J. Cohen, Thinking with Culture in Law and Development, 57 BuFF. L. REV. 511 (2009).

${ }^{110}$ Menkel-Meadow, supra note 91, at 24-25. James Fishkin's work on deliberative polling provides another good example of this call for engineering and control in the name of constructive popular deliberation. See, e.g., JAMES S. FISHKIN, WHEN THE PEOPLE SPEAK: Deliberative Democracy and Public Consultation 106-33 (2009) (describing case examples that offer methods for selecting participants, assessing their understanding and educating them about the matter at hand, and structuring the questions they answer and the conversations they have with others). Indeed, Fishkin argued that the health care town hall meetings would have been far more productive if they were run according to his model, including pre-meeting surveys of local attitudes and demographics, random selection of invited constituents, balanced briefing materials to educate participants, small-group discussions, and "trained moderators [to] make sure that every voice is heard and that the group carefully and thoughtfully narrows in on its most pertinent and pressing policy questions." James Fishkin, Op-Ed., Town Halls by Invitation, N.Y. TIMES, Aug. 16, 2009, at WK9; see also BRUCE ACKERMAN \& JAMES S. FISHKIN, DELIBERATION DAY (2004); Bruce 
likely to remain adversarial and antagonistic, constructive interventions are likely to falter, and attempts to generate new inventive forms of legality are likely to dissipate in the form of polarized and unyielding positions.

This emphasis on expert control, in turn, points to some of the possible limitations of efforts to institutionalize the anti-authoritarian impulses in (at least the more directly populist conceptions of) the progressive constitutionalist vision. By regularizing a particular set of social practices as the appropriate way to self-govern difference, the laws of alternatives suggest the limits of designing extrajudicial professional interventions that aim to empower without also simultaneously aiming to discipline how ordinary people engage democratically with law. Moreover, they illustrate a particular disciplining vision with its own costs and benefits: movements that follow the laws of alternatives do not aim to produce left versions of Tea Party activists with renewed rules for radicals but rather pragmatic problem solvers who are capable and willing to cultivate particular kinds of processes, interests, and ends.

\section{CONCLUSION}

Some of the most important legal theorists of our time have issued sustained scholarly calls to engage ordinary people in constitutional dialogue and public lawmaking in ways that transcend, if not transform, our current legal regime with its court-centered focus. In this Article, we traced the routes of an analogous (albeit more private and small-scale) set of ambitions within the field of alternative dispute resolution. We emphasized the commonalities between a strand of early mediation and the anti-authoritarian aspirations of progressive constitutionalism, yet we also cautioned that, as a matter of actual practice, the progressive potential of mediation gave way to a discourse of management, service delivery, and efficiency. At the same time, however, we argued that ADR's legacy today is not only a set of private, managerial, bureaucratic institutions dedicated to court reform and efficiency maximization but also alternative jurisprudential ideals-what we called the laws of alternatives- that have been developed by legal scholars and practitioners and reproduced in law schools and throughout the legal profession over the past four decades. These ideals continue to inspire renewed and now often large-scale aspirations for the progressive possibilities of collaborative dialogic exchange. ${ }^{111}$

Ackerman, The Citizenship Agenda, in THE CONSTITUTION IN 2020, supra note 5, at 109, 113-14 (describing Ackerman and Fishkin's proposal to use deliberative polling as the basis of a national holiday, "Deliberation Day").

111 See, e.g., Christopher Honeyman \& Andrea Kupfer Schneider, Introduction: $A$ "Canon of Negotiation" Begins to Emerge, in THE NEGOTIATOR's FiELDBOoK, supra note 69 , at 1-2 (arguing for the transformation of theories of private bargaining into a social theory of problem solving and "peacemaking ... at many levels"); Joseph P. Stulberg, Questions, 17 OHIO ST. J. ON DISP. RESOL. 531, 534 (2002) (proposing that, although once 
But rather than offer an uncritical endorsement of the laws of alternatives, our example instead sketched some of the particular and complex ways that alternative legal reform movements aspire to infuse democratic legal engagement with particular kinds of democratic disciplining. It is a point that our early-twentieth century Progressives knew well. Mary Parker Follett (a theorist whose work continues to influence contemporary $\mathrm{ADR}^{112}$ ) put the idea quite bluntly in 1918: "We are told that we must elevate the 'people.' There are no 'people.' We have to create a people." 113 It is also a point that MenkelMeadow openly and, to her credit, quite ambivalently acknowledges. On the one hand, she argues that dialogic preconditions and skilled facilitation appear necessary to orchestrate popular political/legal engagement on a societal scale. On the other hand, however, she questions how practitioners of democratic deliberation and dispute resolution should legitimate and justify their "hierarchical structure of procedural expertise."114 "If scaled-up deliberation requires leadership and facilitation," she writes, "what is the theory behind expert facilitation in democratic models of equal participation? If thoughtful deliberation requires adequate preparation and education ..., how democratic can the process be with teachers, leaders, guides, and dedicated time commitments?"115 Larry Kramer offers a similar observation when he ventures that the Left's embrace of deliberative democracy reflects its mistrust not its endorsement of popular government. Deliberative democracy, he argues, is

a philosophical school that emphasizes preconditions for legitimate rule and that turns out to be mostly about deliberation and hardly at all about democracy. Popular rule is legitimate, we are told, only if certain stringent prerequisites are satisfied: prerequisites that it just so happens can be met only by small bodies far removed from direct popular control. ${ }^{116}$

We have argued here that this tension between populism and expertise, empowerment and management, opposition and collaboration, disruption and consensus, indeed, democracy and control is intrinsic to legal reform movements that follow the laws of alternatives. They are an effort, like law

debatable, the evidence now overwhelmingly supports the idea that mediation is appropriate for "the most complex ... social controversies of our time"); see also supra note 63 .

112 See, e.g., FiSHER \& URY, supra note 64, at vii; RICHARD E. WALTON \& ROBERT B. McKersie, A Behavioral Theory of Labor Negotiations: AN ANALysis of a Social INTERACTION SYSTEM 7, 128, 148 (1965); Albie M. Davis, An Interview with Mary Parker Follett, 5 NEGOT. J. 223 (1989); Kolb, supra note 75; Menkel-Meadow, supra note 71, at 7 10; Valerie A. Sanchez, Back to the Future of ADR: Negotiating Justice and Human Needs, 18 OHIO ST. J. ON DISP. RESOL. 669, 684-88 (2003).

113 M.P. Follett, The New State: Group Organization the Solution of Popular GOVERNMENT 220 (Peter Smith ed., 1965) (1918).

114 Menkel-Meadow, supra note 91 , at 26.

${ }^{115}$ Id. at 19.

116 Kramer, THE PEOPLE THEMSELVES, supra note 2, at 244. 
itself, simultaneously to enable and constrain social collaboration through a set of values and practices that govern the resolution of difference. But unlike more conventional forms of legal ordering, they aim to achieve this end through creating concrete, if also circumscribed, spaces for popular participation.

We thus end on an ambivalent note. We are proposing that the laws of alternatives are potentially valuable for a movement like progressive constitutionalism. First, they chip away at the idea of adjudication as a privileged site to solve social problems, often at the level of conflict most relevant to everyday life. Second, they point towards a way for popular engagement to become its own regularized tool of democratic governance and practical institutionalized end. Taking seriously the intersubjective, polyvocal, and inventive dialogue that the laws of alternatives envision-and the structural conditions that could make such dialogue more possible-is, in our view, a worthy and progressive aim.

At the same time, however, the laws of alternatives anticipate-or rather they purposefully build into their institutional practice-the costs of their success. As the sociologist Francesca Polletta argues, some of the most important progressive reforms in the United States "for racial and gender equality, civil liberties, consumer protection, and workers" rights" have come from social movements that "have been oppositional, disruptive, and sometimes downright uncivil. They are the unruly mobs that Athenians worried about and that contemporary champions of participatory democracy have sometimes ignored altogether ...."117 When governors and analysts embrace the laws of alternatives - or, as in the example above, propose to apply them as principles of popular engagement with constitutional questions-they do not simply express a desire to trade the authority and hierarchy of adjudication for bottomup empowerment and directly democratic participation in the production of social order and law. They also express a desire to trade defiant political struggle and direct confrontation for procedural governance, partisan solidarity for empathy and depersonalization, and disruptive opposition for dialogic exchange that emphasizes moderation, compromise, and agreement. Progressives-at least those who understand themselves not only as expert designers of large-scale governance institutions but also as participants themselves in social, political, and legal struggles-will, no doubt, debate these tradeoffs and the complex balances that agents can, of course, strike among them. At different moments in American history and under different conditions of structural power, we suspect they will appear more or less desirable-both as a set of normative ideals to inspire a populace willing to question the boundaries between itself and its leaders, and as a set of concrete, pragmatic strategies to achieve left political ends.

117 Francesca Polletta, Freedom Is an Endless MeEting: Democracy in AMERICAN SOCIAL MOVEMENTS 230 (2002). 
